\title{
Model Pengembangan Pendidikan Pesantren Muhammadiyah Boarding School Jombang
}

\author{
Furqon ${ }^{1}$ \\ Dr. Isa Anshori, M.SI \\ Program Studi Magister Manajemen Pendidikan Islam, \\ Universitas Muhammadiyah Sidoarjo, Indonesia \\ Furqonstar1@gmail.com@Umsida.ac.id, \\ Isa_umsida67@yahoo.com@umsida.ac.id
}

\begin{abstract}
This research aims to understand about the education developing model of MuhammadiyahBoarding School Jombang, factor endowments and a barrier, as well as the efforts of addressing and resolving the various obstacles.

This research uses qualitative methods with a phenomenology approach to the subject: caregivers, ustadz - ustadzah and director ofMuhammadiyah Boarding School Jombang. This research uses data collection techniques of observation, interview, and document. Whereas the data collected is analyzed through the stages of data reduction, data display and take conclusion.

The results showed that the education developing model of Muhammadiyah Boarding School Jombang combines educational systemof formal education by using ekspositori strategies, inquiry, CTL,as well as evaluation system formative and summative. In this boarding schools utilizes information and communication technologies as a means of supporting education and quality of ustadz- ustadzahin accordance with the field of their education, barriers in these boarding schools is the lack of ustadz ustadzah qualified and competent in their field, not the lack of adequate facilities and infrastructure, and lack of funding there are various attempts are made to overcome these obstacles include: improving the quality of human resources (ustadz - ustadzah), searching for ustadz - ustadzah that corresponds to the field of education, to improve the existing infrastructure as well as cooperation with communities and agencies for the provision of infrastructure and the provision of funds.
\end{abstract}

Keywords: Development, Education.

\section{INTRODUCTION}

Jombang is a Naat Nahdliyyin region, as evidenced by 87 number of pesantren in Jombang Regency. $97 \%$ of boarding school courtesy of Nahdatul Ulama and Muhammadiyah-owned boarding school only 3 . This happens, as this is the first place to the emergence of the Organization Nahdatul Ulama. What about the Muhammadiyah?

Muhammadiayah appeared in Jombang circa 1950's carry by a figure of that era, namely Venus Kusumo, a CIVIL SERVANT in a number of agencies in the area. The way that he is sharing discussion. He thought the discussion could be shaping the mindset of society as a veiled. In the beginning, Muhammadiyah in spreading many challenges faced, similar to that experienced by KH Ahmad Dahlan, that is dimusuhi by the community. But with seriousness and tenacity of the Muhammadiyah sysop so that can exist and the strong Muhammadiyah until now. Quantitatively is indeed a minority, but the Muhammadiyah in Ticino from the early could build Charity Business Muhammadiyah (AUM), in the form of primary school Muhammadiyah and Study Hall, and the numbers are growing. Muhammadiyah Boarding School (MBS) Stubs which opened in 2014 before is a cottage which was already closed by owner i.e. h. Hasan, then in wakafkan to the Regional Leader of Muhammadiyah in Jombang.

In its development the Cottages originally13 students, and the buildings are not groomed now 215 students and buildings already meets all the needs of the students. Top Regional Leader of Muhammadiyah sooth Jombang manage boarding schools, the diwakafkan Hut to the Muhammadiyah which initially there is no capital at all, now in its $4^{\text {th }}$ year of being able to compete with the hut - huts that have long. Boarding schools also bring many MBS Jombang pretasi good local level to central level. In this case the achievements gained are the winners of the race Tahfidz tinggkat national and East Java, the sacred Footprint Champion Level Java and the language of United Kingdom Champion, national and other levels - even new - this new boarding schools 
Muhammadiyah crowned by the work Education Indonesia 2017 as the favorite in the Islamic school quality and the best quality ofeducation.

Certainly in many development constraints as a barrier to the development of boarding schools, but all of these constraints can be resolved bit by bit over synergy nanny with the Manager and the head Area of Muhammadiyah Jombang, and related parties, ranging from the fulfillment of the development funds, improved model of learning and teaching, as well as improved quality of ustadz/her home.

Then how to Model the development of Pesantren education MBS jombang? Kenala-what are the barriers encountered and how to solve the various obstacles? How is its continuity in the future? Departing from the various problems the author wishes to research about "DEVELOPMENT EDUCATIONAL MODEL OF MUHAMMADIYAH BOARDING SCHOOL JOMBANG".

\section{MAIN PART}

This research usesQualitative approach method of Phenomenology. Qualitative research is intended to interpret the genesis of something that experienced subject research such as behavior, presumption, encouragement, actions, etc., holistically, and elaborate on the way in the form of writings and languages, at a special events naturally by using natural methods. Phenomenology attempts to approach focuses on the human experience of life and as a tool for better understanding of the social, cultural.

The data source used is the visual video, documents, and photos, are then collected by conducting observations and interviews.

\section{A. UNDERSTANDING}

\section{RESULTS}

According to the great dictionary of the language of Indonesia is an example of a Model that will be generated. Meanwhile, according to M. Arifin Model is a description of something real, e.g. a ship model is an Benchmark of something that will be created. According to the great dictionary of the language of Indonesia sense "development" is one that is done to develop. Is the development in this respect is the way that is done, to developing the pesantren education system. So the link with the title of the thesis is the development education Model of Muhammadiyah Boarding School Stubs.

According to Marwan Saridjo boarding schools are educational institutions that teach islam pendidikanya system with the santrinya provided pondokkan or residence and also organises formal education in the form of a public school in the various levels of vocational and according to expected community respectively

\section{B. SORT - SORTS EDUCATION DEVELOPMENT MODEL OF BOARDING}

\section{Salafiyah Boarding School}

Salafiyah Boarding schools is the cottage which has a model of science teaching - the science of religion. As his model retains the boarding procedures and model his education from the first pertumbuhanya. Teaching and learning in the boarding school could be done by way of classical or non classical. Model huts like this using the curriculum itself in terms of its own designed according the hallmark of pesantren. Perjenjang done by distinguishing the book higher after mentamatkan a particular book.

\section{Khalafiyah Boarding School}

Khalafiyah boarding school was a but also newfangled held a good formal education, elementary, junior high, HIGH SCHOOL or even noodles, MTs, MA are characteristic of religion. There are two models of this form of Pesantren khalaf that can be taken that is prominent, meaning students could reside or not, and also the second model that is exclusively where the students all have to stay Boarding. Win ushuludin also says that you can classify Khalafi into three large groups:

a) Khalafiyah boarding school in which there is a system of professional teaching and learning in the form of know-how, this also includes the order must exist in formal education.

b) Boarding schools that already had institutions - institutions or madrasah is also included in the most important part of the education system, the aim is also to develop a career and make professionalism of teachers of Islam.

c) Boarding school to hold a formal school to aim so that his protégé participants prepare to move on to the high level of perguaruan but with sufficient Islamic capital, so that later became an educated muslim High knowledge Islam. 


\section{DEVELOPMENT EDUCATION MODEL OF MUHAMMADIYAH BOARDING SCHOOL JOMBANG}

1. Combine the curriculum of Formal Curriculum with Cottage by combining this curriculum expected Boarding Boarding School Muhammadiyah Jombang were able to solve the problems that concern with moral and ethical students and also mencabarkan function of national education which develops the ability students also build character and the civilization of the nation in the enlightened students.

The Muhammadiyah Islamic boarding school in Jombang manage and cultivate our learning implemented various strategies, models and learning methods as follows:

a) Strategy ekspositori

b) Strategy of Inquiry

c) Contextual Teaching Learning Strategies

2. The management of the Infrastructure

According to Drs. Mohammad Irham said infrastructure is the supporting tool in the effort do education because if the facilities and infrastructure are met then it will achieve the expected education.

In Boarding facilities and infrastructure of Muhammadiyah Boarding School in Jombang kept increases the and continue to meet the needs of a boarding school, from which only the initial priode Naat Naat dormitory building 13 no class and used create a learning leaking not groomed, now with the increase of the Muhammadiyah students boarding Boarding School in Jombang kept increases the and constructed as Muhammadiyah Jombang build classes to the Princess as well as add two levels of learning facilities such as: LCD 4 pieces, olaraga equipment, equipment extra music, etc.

3. The qualified Educators

4. Procurement of Funds

5. Quality Assurance System

This quality assurance system well as developing the infrastructure facilities of the building, mainly of second-year boarding school Muhammadiyah Boarding School Jombang build dormitory student daughter, third year student dormitory building son two levels as well as the merenofasi class that is used for learning, the fourth year now build the mosque as a means of meeting students and beribadahan students and in This fifth Boarding Boarding School so should be implemented all ustadz - ustadzah so education is achieved in accordance with the standarkan, this time in the priode previously santrinya is still a quality assurance system for students 9 it consists only of the head the school or the caregiver as well as team founder Muhammadiyah Islamic boarding school Jombang and this time goes by and the students Increased much so that this quality assurance team that originally only discussed by the principal or the caregiver as well as team founder Muhammadiyah Boarding School in Jombang are now principals and caregivers have established a quality assurance system to implement so that future Muhammadiyah Boarding School in Jombang into quality.

\section{THE FACTORS OF RESTRICTING DEVELOPMENT A SUPPORTERS OF MUHAMMADIYAH BOARDING SCHOOL IN JOMBANG \\ 1. Curriculum}

Factors restricting the development of MBS in education field the curriculum is:

a) Infrastructure Limitations

b) Weak supervision of Ustad-Ustadzah in the field that caused the level of Discipline is quite low.

c) Lack the glaring discrepancy between the ustadz-ustadzah with the field of education

d) Strategy approach to Learning doesn't always run smoothly

\section{The lack of infrastructure}

From the beginning since in wakafkan to the Muhammadiyah until coined to establish Boarding School Muhammadiyah in Jombang Leadership Area Jombang not provide what - what so to advance the Muhammadiyah in Jombang this nanny still Open boarding facility with this potluck and no help from its central JUNIOR HIGH SCHOOL.

3. The Lack Of Quality Of Human Resources

4. Lack Of Funds

According to Atik Mudah MulyasariYoung's lack of economy of society also cause obstructions in the procurement of funds. In addition to the factors that hampered the development education of Muhammadiyah Boarding School Jombang there is also a factor - factors supporting the development of education MBS Jombang as follows: 
1. Curriculum

The plan combines the curriculum is also tailored to the needs of the students and also the development of the draft boarding school Muhammadiyah Center instructional Curriculum boarding school with a Formal Curriculum must be combined so that time playing Rasta not taken by the teaching and learning activities and fill in for selfdevelopment students.

\section{Supervise and care for Infrastructure}

3.Suitability of Ustadz - ustadzah lesson material with ustadz - ustadzah Muhammadiyah Boarding School in Jombang not only controlled in terms of classroom management but are required to have a good personality wise, thoughtful as well as being a model for learners according to the nanny the success of any Boarding School Development not only in specified by Ustadz skills - ustadzah in processing the class but is determined also by the good akhlaq by Ustadz - ustadzah that as an example as well as older people both in Muhammadiyah Boarding School Jombang.

\section{The existence of sufficient funds}

Each institution be it formal or boarding must need the name of the Fund for developing the Pendidikanya, then in practice for mengadaan these funds should be regulated effectively and efficiently. Funds in Management for development is important because any development planning requires not only fund the development activities are also the same.

\section{E. EFFORTS ARE BEING MADE TO RESOLVE THE BARRIERS}

In the development of Muhammadiyah.Boarding School in Jombang.

1. Curriculum

a) Ustadz - Ustadzah must be more creative to make learning materials

b) Supervision of the Ustadz - Ustadzah so that Discipline Be Increased

c) Finding the Ustadzah fit with the field of Education

d) Application of appropriate Learning Strategies with the ability of the child

\section{Procurement Infrastructure}

3. Improve the quality of Ustadz - Ustadzah

In improving the Ustadz - ustadzah is also the aspect that must be considered incorrect, useless when the curriculum already combined infrastructure already being met but the lack of quality of the Ustadz - ustadzah. According to Amm Qurrota A'yan used to say that by holding a brief training education expected Ustadz ustadzah could benefit in the training so that it can be applied in the learning of the students.

So no Ustadz - ustadzah required to improve the teaching quality of the course but also demanded to raise the spiritual quality of the minimum can read the Qur'an was a major key in the reception of Ustadz - ustadzah.

\section{Procurement of Funds}

According to the nanny that when we want to develop something we must start from ourselves. To meet the needs of existing funds caregiver copes lent those funds with private money for the development and progress of the Muhammadiyah Islamic Boarding School Jombang. So the efforts made the nanny in developing the Boarding School Muhammadiyah in Jombang Cover underfunded with lent those funds with private money as well as establish rapport with communities that want to give ready donasinya for advancement of Muhammadiyah Boarding School in Jombang and money monthly students.

\section{CONCLUTION}

With memperharhatikan various exposure above on previous chapters can be concluded that:

1) Muhammadiyah Boarding School in Jombang develop a Model Modern boarding schools, namely mixing system of schooling and kepesantrenan system, combining the two into a single curriculum and use strategy approach Ekspositori Contextual Inquiry, Teaching, Learning, as well as holding infrastructure, ustadz quality ustadzah - in accordance with their fields and excavation funds for development of Pesantren education MBS Jombang. To guarantee the quality of Pesantren education Boarding School Muhammadiyah Jombang to form teams to perform repairs - repairs To improve the quality of Pesantren education MBS Jombang.

2) There are several factors barrier in thendevelopment of pesantren MBS Jombang, namely weak supervision Ustadza - ustadzah approaches, lack of infrastructure, and the quality of the Ustadz -ustadzah, lack of interest and talents of students, as well as the limitation of funds. As for the supporting factor is the 
fighting spirit of the Ustadz - ustadzah in carrying out tasks and support both in the Assembly of the Fund as well as managerial.

3) Efforts are being made to overcome the barriers - these obstacles was told Ustadz - ustadzah for more creative in making learning materials, discipline, recruiting Ustadz - ustadzah that corresponds to the field of education, as well as repair and renovate sarpras that can still be used for learning, held a brief training each year to improve the quality of self Ustadz - ustadzah. In addition, to procure funds, private funds, lent the nanny.

Boarding School Muhammadiyah in Jombang has been developed using the model of development in an integrated and modern, yet still have weaknesses in the quality of human resources and infrastructure, as well as the limited funds. The future implications of the boarding school could never be developed without any increase in the quality of human resources, provision of infrastructure and sources of funds, because it then various attempts to improve the quality of HUMAN RESOURCES and the excavation of the source source of funds should always be performed. In this case the required cooperation with communities, businesses, and industry. As well as various parties, not only for extracting the funds but for the enhancement of HUMAN RESOURCES. 